\section{Effects of Substrate Type on Plant Growth and Nitrate Leaching in Cut Flower Production of Oriental Lily}

\author{
Don Merhaut and Julie Newman \\ University of California-Riverside, Department of Botany and Plant Sciences, \\ 4118 Batchelor Hall, Riverside, CA 92521
}

Additional index words. Lilium 'Starfighter', Lilium 'Casa Blanca', coir, peat, nitrogen, plant growth

\begin{abstract}
Four types of media [coir, 1 coir : 1 peat (by volume), peat, and sandy loam soil] were evaluated for their effects on plant growth and nitrate $\left(\mathrm{NO}_{3}^{-}\right)$leaching in the production of oriental lilies (Lilium L.) 'Starfighter' and 'Casa Blanca'. Twenty-five bulbs were planted in perforated plastic crates and placed on the ground in temperature-controlled greenhouses. The potential for $\mathrm{NO}_{3}^{-}$leaching was determined by placing an ion-exchange resin (IER) bag under each crate at the beginning of the study. After plant harvest (14 to 16 weeks), resin bags were collected and analyzed for $\mathrm{NO}_{3}^{-}$content. Plant tissues were dried, ground, and analyzed for $\mathrm{N}$ content. Results indicated that the use of coir and peat did not significantly influence plant growth (shoot dry weight) relative to the use of sandy loam soil; however, substrate type influenced the amount of $\mathrm{NO}_{3}^{-}$leached through the media and $\mathbf{N}$ accumulation in the shoots for 'Starfighter', but not 'Casa Blanca'.
\end{abstract}

State and local legislation often dictate that nutrient runoff from nonpoint sources, such as nurseries, must be mitigated if runoff water is being discharged into impaired water bodies. Current federal policies indicate that reservoirs that are used for drinking purposes cannot have nitrate-nitrogen $\left(\mathrm{NO}_{3}^{-}-\mathrm{N}\right)$ concentrations in excess of $10 \mathrm{mg} \cdot \mathrm{L}^{-1}$. These concentrations are low, when compared to the concentrations used in typical nursery production systems, which are as high as $200 \mathrm{mg} \cdot \mathrm{L}^{-1}$. In various areas of California, nurseries must develop and present a plan of best management practices (BMPs) according to the guidelines set forth by their Regional Water Quality Control Board (RWQCB) and begin implementing these BMPs by the year 2007. Because of the rapid execution of these policies, it is imperative that BMPs are quickly developed to mitigate nutrient leaching and runoff. However, very little data regarding nutrient leaching from nurseries are available.

The nursery and floriculture enterprises most impacted by these water quality regulations are those that are in close proximity to surface waters. In California a large ornamental production industry, which includes cut lily flowers, is situated along the coast. The mild climate of this region allows year-round production of lilies, resulting in over 58 million dollars in revenue per year for the California economy (U.S. Department of Agriculture, 2003).

Lily production in this region is commonly done by planting bulbs in the field or in large crates filled with soil or other substrates. These crates are then placed on the ground in greenhouses or shade houses. Growers tradi-

Received for publication 28 June 2005. Accepted for publication 3 Aug. 2005.

${ }^{1}$ To whom reprint requests should be addressed; e-mail donald.merhaut@ucr.edu. tionally use field soils as the planting media, since it is relatively inexpensive compared to artificial substrates such as peat, perlite, or coir. However, growers who do not have access to suitable soils typically use peatmoss or coir. Lilies have been grown in a variety of media ranging from $100 \%$ soil to $100 \%$ peat (Berghaef, 1985; Hanks and Menhenett, 1980), but there is no information available comparing the effects of soils versus artificial organic substrates on plant growth and $\mathrm{NO}_{3}^{-}$leaching. The objective of the following study was to evaluate the effects of different media on plant growth and $\mathrm{NO}_{3}{ }^{-}$leaching in an effort to determine if substrate selection could mitigate $\mathrm{NO}_{3}^{-}$leaching while concurrently maintaining or improving plant production for cut flower oriental lilies.

\section{Materials and Methods}

Plant material. The following studies were conducted using two cultivars of commercially available oriental lilies (Lilium L.), 'Starfighter' and 'Casa Blanca' (Sun Valley Holland, Breezand, Holland). Average bulb circumference was 16 to $18 \mathrm{~cm}$ and 18 to $20 \mathrm{~cm}$ for 'Starfighter' and 'Casa Blanca', respectively. 'Starfighter' was used in Expt. 1, with bulbs planted on 21 Aug. 2003 and plants harvested on 2 Jan. 2004. The cultivar 'Casa Blanca' was used in Expt. 2, with bulbs planted on 12 Sept. 2003 and plants harvested on $23 \mathrm{Feb} .2004$. At the end of the study, plant shoots were harvested, dried at 70 ${ }^{\circ} \mathrm{C}$, and weighed. Total $\mathrm{N}$ was determined using the N-combustion method (Sweeney, 1989). Total $\mathrm{K}$ was determined by $2 \%$ acetic acid extraction and quantified by atomic emission spectrometry (AES) (Franson, 1985; Johnson and Ulrich, 1959) and total phosphorus (P) was determined through microwave digestion with nitric acid and hydrogen peroxide and quantified by atomic absorption spectrometry
(AAS) (Meyer and Keliher, 1992; Sah and Miller, 1992).

Media treatments. Four types of media were tested: 1) sandy loam soil from coastal alluvial deposits located in Arcata, Calif.; 2) coir(SAI International Trading Corp., Oxnard, Calif.); 3) peatmoss (Premier Horticulture Inc., Red Hill, Pa.); and 4) 1 coir : 1 peat (by volume). Coir was supplied in the form of compressed bricks $(25 \times 15 \times 27 \mathrm{~cm})$, and peat was supplied as compressed bails $(0.108$ $\mathrm{m}^{3}$ ). Both substrates were hydrated according to manufacturer guidelines. Physical characteristics of the media were determined in 0.39 $\mathrm{L}(8.5 \times 8.5 \times 6.5 \mathrm{~cm})$ containers according to the methods described by Niedziela and Nelson (1992) and all chemical analyses were conducted at the University of California's Agricultural and Natural Resources (ANR) Laboratory in Davis, Calif. Total $\mathrm{N}$ of all substrates was quantitatively determined using the N-combustion method (Sweeney, 1989). Exchangeable K was determined by extracting soils with $1 \mathrm{~N}$ ammonium acetate (pH 7.0) (Knudsen et al., 1982) and extracting organic media with $2 \%$ acetic acid (Johnson and Ulrich, 1959). Potassium concentration of extracts was determined using AES (Franson, 1985). Phosphorus concentration of organic media was determined using a nitric acid/hydrogen peroxide microwave digestion and inductively coupled plasma-atomic emission spectrometry (ICP-AES) (Meyer and Keliher, 1992; Sah and Miller, 1992). Exchangeable P of soil was determined by the Olsen method (Olsen and Sommers, 1982; Prokopy, 1995). Physical characteristics of the three organic media were similar to each other (Table 1). The sandy loam had a higher bulk density and lower water holding capacity than the organic media. Chemical characteristics such as the $\mathrm{N}$ concentration $(0.58 \%$ to $0.95 \%)$ and the $\mathrm{P}$ concentration (about $0.02 \%$ ) were similar for all treatments (Table 1). However, the electrical conductivity (EC) differed between media, with the sandy loam having the highest EC $\left(3.44 \mathrm{dS} \cdot \mathrm{m}^{-1}\right)$ and the sphagnum peat having the lowest EC $\left(0.10 \mathrm{dS} \cdot \mathrm{m}^{-1}\right)$. Total potassium concentrations also varied between media types, with sphagnum peat having the lowest $\mathrm{K}$ concentration $(<0.05)$ and the coir having the highest $\mathrm{K}$ concentration (1.01\%).

Planting and cultural methods. All experiments were conducted at a commercial nursery located in Oxnard, Calif. Common cultural practices of the region were followed as described. Twenty-five bulbs were planted in each perforated $0.04-\mathrm{m}^{3}(56 \times 36 \times 20-\mathrm{cm})$ plastic crate, which was filled with one of the four experimental substrates. Each planted crate represented one replication, with four replications per treatment. Planted crates were stored in sheds at $14{ }^{\circ} \mathrm{C}$ for 3 weeks to initiate root development. Crates containing the root-initiated bulbs were then moved to the greenhouse and placed on the ground in rows that were two crates wide $(0.72 \mathrm{~m}) \times 30$ crates long $(16.80 \mathrm{~m})$ in a randomized complete block design. Greenhouse average high and low temperatures were maintained at 18 and $16^{\circ} \mathrm{C}$ respectively. Plants were irrigated using 
Table 1. Physical and chemical characteristics of the four media types. Water-holding capacity was determined by calculating differences between media weight at field capacity versus media weight after oven drying. Values are the means of five replications.

\begin{tabular}{|c|c|c|c|c|c|c|c|c|}
\hline Substrate & $\begin{array}{c}\text { Bulk } \\
\text { density } \\
\left(\mathrm{g} \cdot \mathrm{cm}^{-3}\right)\end{array}$ & $\begin{array}{l}\text { Water- } \\
\text { holding } \\
\text { capacity } \\
\text { (\% by vol) }\end{array}$ & $\begin{array}{l}\text { Air-filled } \\
\text { porosity } \\
\text { (\% by vol) }\end{array}$ & $\mathrm{pH}$ & $\begin{array}{l}\text { Electrical } \\
\text { conductivity } \\
\left(\mathrm{dS} \cdot \mathrm{m}^{-1}\right)\end{array}$ & $\begin{array}{c}\text { Total } \\
\mathrm{N} \\
(\%)\end{array}$ & $\begin{array}{l}\text { Total } \\
\mathrm{P} \\
(\%)\end{array}$ & $\begin{array}{c}\text { Total } \\
\text { K } \\
(\%)\end{array}$ \\
\hline$\overline{\text { Coir }}$ & 0.07 & 60.0 & 8.8 & 5.91 & 0.71 & 0.63 & 0.03 & 1.01 \\
\hline 1 Coir : 1 sphagnum peat (by volume) & 0.06 & 63.1 & 10.1 & 4.84 & 0.53 & 0.78 & 0.03 & 0.63 \\
\hline Sandy loam & 0.54 & 17.0 & 6.4 & 5.87 & 3.44 & 0.58 & 0.01 & 0.93 \\
\hline
\end{tabular}

two rows of drip tape placed down the length of each crate with water applied at a rate of $90 \mathrm{~L} \cdot \mathrm{m}^{-2}$ in one irrigation event, three times a week. Fertilization occurred through the irrigation system at each irrigation, supplying: $\left(\mathrm{mg} \cdot \mathrm{L}^{-1}\right) 180 \mathrm{NO}_{3}^{-}-\mathrm{N}, 5.00 \mathrm{NH}_{4}^{+}-\mathrm{N}, 35.0 \mathrm{P}$, $275 \mathrm{~K}, 160 \mathrm{Ca}, 45^{3} \mathrm{Mg}, 5.00 \mathrm{Fe}, 1.00 \mathrm{Mn}, 0.54$ $\mathrm{Zn}, 0.05 \mathrm{~B}, 0.66 \mathrm{Cu}$, and $0.56 \mathrm{Mo}$. Two weeks after containers were placed in the greenhouse, plants received a topical application of granular calcium nitrate at $139 \mathrm{~g} \cdot \mathrm{m}^{-2}$.

Nitrate uptake and leaching measurements. Nitrate leaching was determined through the use of $\left(5 \times 5 \times 0.25 \mathrm{~cm}^{2}\right)$ ion-exchange resin (IER) bags that were constructed according to the procedures described by Wyland and Jackson (1993). Each IER bag contained 5.4 $\mathrm{g}$ of AG 1-X8 anion exchange resin beads, size 300-1180 $\mu \mathrm{m}$ (BioRad Laboratories, Richmond, Calif.). AG1-X8 resin has a greater affinity for $\mathrm{NO}_{3}^{-}$than chloride $(\mathrm{Cl})$; therefore, it acts as a sink for $\mathrm{NO}_{3}^{-}$. Bags were stored in $1 \mathrm{M}$ potassium chloride $(\mathrm{KCl})$. Before use, bags were rinsed with two 10-min washes of deionized water. One resin bag was placed directly under the center of each crate after crates were placed in the greenhouse. Drainage was provided between rows to prevent cross contamination of drainage water from other containers. All root growth for all treatments remained within the crates throughout the experiments; therefore, any $\mathrm{NO}_{3}^{-}$that leached out of the crates and into the IER bags would be unavailable for plant uptake and would be considered a potential leaching hazard. At the end of each experiment, resin bags were collected, individually sealed in plastic bags, and refrigerated until $\mathrm{NO}_{3}^{-}$was extracted. All extractions were conducted within $24 \mathrm{~h}$ after harvest. Nitrate was extracted by placing each IER bag in an erlenmeyer flask containing $250 \mathrm{~mL}$ of $2 \mathrm{M} \mathrm{KCl}$ and shaking flasks at 130 rpm for $12 \mathrm{~h}$ with an orbit shaker (Lab-Line \#3590; Melrose Park, Ill.). This procedure was repeated three times, and the resulting extractants were combined and refrigerated until analyses. Nitrate concentration of extracts was determined colorimetrically on a SmartChem 200 (Westco Scientific Instruments, Inc., Danbury, Conn.) according to EPA Method 353.2 (Clesceri et al., 1998).

Plant harvesting protocols. Five plants were randomly selected from each replication at anthesis. Entire shoots (leaves, stems, and flowers) were removed, dried at $60{ }^{\circ} \mathrm{C}$, weighed, and ground to $0.420 \mathrm{~mm}$ with a Wiley mill (model \#3; Arthur H. Thomas Co., Philadelphia). Plant samples were analyzed for total $\mathrm{N}$ using the $\mathrm{N}$ combustion method, total P with an ICP-AES (Thermo Electron Corp., Madison, Wis.), and extractable $\mathrm{K}$ with an atomic absorption spectrometer (AAS) (PerkinElmer Life and Analytical Science, Inc., Boston).

Statistical analyses. Statistic analyses of all leachate and plant growth data were conducted using a Proc GLM with SAS Version 9.1 (SAS Institute, Inc., Cary, N.C.).

\section{Results and Discussion}

Plant growth. Overall average shoot dry weight, as means of all media, was 60.1 and 98.7 g for 'Starfighter' and 'Casa Blanca', respectively. For both cultivars, shoot dry weight was not significantly different when comparing the coir and peat substrates with the sandy loam soil (Table 2).

Plant nutrient content. Nitrogen content for 'Starfighter' shoots grown in substrates containing $50 \%$ or $100 \%$ peat was greater than plants grown in sandy loam (Table 2). This effect on $\mathrm{N}$ content was not observed in 'Casa Blanca'. Media had no effect on shoot content of $\mathrm{P}$ and $\mathrm{K}$ for either cultivar (Table 2).

Nitrate leaching. There was significantly less $\mathrm{NO}_{3}^{-}$accumulation into the IER bags placed under the $100 \%$ coir substrate than the sandy loam for 'Starfighter'. However, media type had no effect on $\mathrm{NO}_{3}^{-}$accumulation in the IER bags in the experiment conducted with 'Casa Blanca' (Table 3).

The decreased $\mathrm{NO}_{3}^{-}$leaching in 'Starfighter' with the use of the $100 \%$ coir substrate may be attributed to the binding of $\mathrm{N}$ by the coir as described by Handreck $(1992,1993)$. If this is the case, it may also explain why there was greater $\mathrm{N}$ accumulation in the shoots of 'Starfighter' lilies grown in the peat-containing media compared to the sandy loam soil. Since the average shoot growth of 'Casa Blanca' was $>50 \%$ greater (dry weight), which absorbed twice as much N compared to 'Starfighter', less N leached through the crates, regardless of media type. Based on the results of the present study, it appears that media type may not play a major role in shoot growth and $\mathrm{NO}_{3}^{-}$leaching in oriental lily production, supporting findings by others that oriental lilies adapt quite readily to different media types such as coir, peat, and soil (Dole and Wilkins, 1999; Evans and Iles, 1997; Evans and Stamps, 1996; Mak and

Table 2. Effects of substrate type on total shoot dry weight (DW) and N, P, and K content of shoots of 'Starfighter' and 'Casa Blanca' oriental lilies. Plants were grown for about 16 weeks in the greenhouse and harvested at anthesis. Shoots consisted of stem, leaves, and flowers.

\begin{tabular}{lcccc}
\hline Treatment & $\begin{array}{c}\text { Shoot } \\
\text { DW }(\mathrm{g})\end{array}$ & $\begin{array}{c}\mathrm{N} \\
\text { (g/plant) }\end{array}$ & $\begin{array}{c}\mathrm{P} \\
\text { (g/plant) }\end{array}$ & $\begin{array}{c}\mathrm{K} \\
\text { (g/plant) }\end{array}$ \\
\hline Starfighter & & & & \\
$\quad$ Sandy loam & 56.3 & 1.16 & 0.08 & 1.79 \\
1Coir: 1 peat (v/v) & $64.4^{\mathrm{NS}}$ & $1.41^{*}$ & $0.09^{\mathrm{NS}}$ & $1.98^{\mathrm{NS}}$ \\
$\quad$ Coir & $57.7^{\mathrm{NS}}$ & $1.15^{\mathrm{NS}}$ & $0.08^{\mathrm{NS}}$ & $1.76^{\mathrm{NS}}$ \\
$\quad$ Peat & $61.8^{\mathrm{NS}}$ & $1.47^{*}$ & $0.09^{\mathrm{NS}}$ & $1.77^{\mathrm{NS}}$ \\
Casa Blanca & & & & \\
$\quad$ Sandy loam & 84.4 & 2.06 & 0.18 & 2.90 \\
1 Coir : 1 peat (by volume) & $105.0^{\mathrm{NS}}$ & $2.45^{\mathrm{NS}}$ & $0.19^{\mathrm{NS}}$ & $3.43^{\mathrm{NS}}$ \\
Coir & $97.5^{\mathrm{NS}}$ & $2.07^{\mathrm{NS}}$ & $0.17^{\mathrm{NS}}$ & $3.20^{\mathrm{NS}}$ \\
$\quad$ Peat & $108.0^{\mathrm{NS}}$ & $2.34^{\mathrm{NS}}$ & $0.19^{\mathrm{NS}}$ & $2.63^{\mathrm{NS}}$ \\
\hline
\end{tabular}

NS, ${ }^{*}$ Nonsignificant or significant least square means (of four samples per substrate) from the mean of the sandy loam treatment for each cultivar according to Dunnett's test (two-tailed) at $P \leq 0.10$.

Table 3. Effects of substrate type on nitrate leaching during a 16 week production period for 'Starfighter' and 'Casa Blanca' oriental lilies. At the end of each experiment, resin bags were collected and nitrate was extracted by placing each IER bag into an Erlenmeyer flask containing $250 \mathrm{~mL}$ of $2 \mathrm{M} \mathrm{KCl}$ and shaking for $12 \mathrm{~h}$ according to the procedures described by Wyland and Jackson (1993).

\begin{tabular}{llc}
\hline Cultivar & Substrate & Nitrate-N content (mg) \\
\hline Starfighter & Sandy loam & 32.15 \\
& 1 Coir : 1 peat (by volume) & $12.16^{\mathrm{NS}}$ \\
& Coir & $8.97^{*}$ \\
& Peat & $11.42^{\mathrm{NS}}$ \\
Casa Blanca & & \\
& & \\
& Sandy loam & 10.02 \\
& Coir : 1 peat (by volume) & $10.24^{\mathrm{NS}}$ \\
& Coir & $1.83^{\mathrm{NS}}$ \\
PS, ${ }^{\mathrm{NS}}$ Peat & $5.91^{\mathrm{NS}}$ \\
\hline
\end{tabular}
sandy loam treatment for each cultivar according to Dunnett's test (two-tailed) at $P \leq 0.10$. 
Yeh, 2001; Meerow, 1995; Offord et al, 1998; Stamps and Evans, 1997, 1999).

Improving $\mathrm{N}$ uptake and reducing $\mathrm{NO}_{3}$ leaching through proper selection of substrates (coir, peat, or sandy loam) may be a suitable BMP for production systems where plant growth is less vigorous or where smallergrowing cultivars are cultivated. However, for production systems or cultivars that produce more vegetative growth, selection of media type (coir, peat, or sandy loam) probably will not decrease $\mathrm{NO}_{3}{ }_{3}^{-}$leaching and, therefore, will not be a suitable BMP option. Perhaps more appropriate methods to reduce $\mathrm{NO}_{3}{ }^{-}$leaching and increase $\mathrm{N}$ uptake in oriental lily production systems would be to increase the planting density or decreased $\mathrm{N}$ application rates in situations where plant growth will be less, such as suboptimal environmental conditions or cultivar selections with low vigor.

\section{Literature Cited}

Berghaef, J. 1985. Effect of calcium on tip burn of Lilium 'Pirate'. Acta Hort. 177:433-438.

Clesceri, L.S., A.E. Greenberg, and A.D. Eaton. 1998. Standard methods for the examination of water and wastewater, 20th ed. Amer. Public Health Assn.-Amer. Water Works Assn.-Water Environ. Fed., Wash., D.C.

Dole, J.M. and H.F. Wilkins. 1999. Floriculture: principles and species. Prentice-Hall, Inc., Upper Saddle River, N.J.

Evans, M.R. and J.K. Iles. 1997. Growth of Viburnum dentatum and Syringa $\times$ prestoniae 'Donald Wyman' in sphagnum peat and coir dust-based substrates. J. Environ. Hort. 15:156-159.
Evans, M.R. and R.H. Stamps. 1996. Growth of bedding plants in sphagnum peat and coir dust-based substrates. J. Environ. Hort. 14:1287-1290.

Franson, M.A. 1985. Method 303A, p. 157-160. In: M.A. Franson (ed.). Standard methods for the examination of water and wastewater. 16th ed. Amer. Public Health Assn.-Amer. Water Works Assn.-Water Pollution Control Fed., Wash., D.C.

Handreck, K.A. 1992. Rapid assessment of the rate of nitrogen immobilization in organic components of potting media: I. Method development. Commun. Soil. Sci. Plant Anal. 23:201-215.

Handreck, K.A. 1993. Properties of coir dust, and its use in the formulation of soilless potting media. Commun. Soil Sci. Plant Anal. 24:349-363.

Hanks, G.R. and R. Menhenett. 1980. An evaluation of new growth retardants on mid-century hybrid lilies. Scientia Hort. 13:349-359.

Johnson, C.M. and A. Ulrich. 1959. Analytical methods for use in plant analysis. Univ. Calif. Agr. Expt. Sta. Res. Bul. 766.

Knudsen, D., G.A. Peterson, and P.F. Pratt. 1982. Lithium, sodium and potassium, p. 225-246. In: A.L. Page, R.H. Miller, and D.R. Keeney (eds.). Methods of soil analysis. Part 2. Chemi$\mathrm{cal}$ and microbiological properties. Amer. Soc. Agron.-Soil Sci. Soc. Amer., Madison, Wis.

Mak,A.T.Y. and D.M. Yeh. 2001. Nitrogen nutrition of Spathiphyllum 'Sensation' grown in sphagnum peat- and coir-based media with two irrigation methods. HortScience 36:645-649.

Meerow, A.W. 1995. Growth of two tropical foliage plants using coir dust as a container medium amendment. HortTechnology 5:237-239.

Meyer, G. A. and P. N. Keliher. 1992. An overview of analysis by inductively coupled plasmaatomic emission spectrometry, p. 473-505. In: A. Montaser and D.W. Golightly (eds.). Inductively coupled plasmas in analytical atomic spectrometry. VCH Publ., Inc., New York.

Niedziela, Jr., C.E. and P.V. Nelson. 1992. A rapid method for determining physical properties of undisturbed substrate. HortScience 27:1279-1280.

Offord, C.A., S. Muir, and J.L. Tyler. 1998. Growth of selected Australian plants in soilless media using coir as a substitute for peat. Austral. J. Expt. Agr. 38:879-887.

Olsen, S.R. and L.E. Sommers. 1982. Phosphorus, p. 403-430. In: A.L. Page, R.H. Miller, O.R. Keeney, and D.E. Baker (eds.). Methods of soil analysis: Part 2. Chemical and microbiological properties. Agron. Soc. Amer. Monogr. 9.

Prokopy, W.R. 1995. Phosphorus in 0.5 м sodium bicarbonate soil extracts. QuikChem method 12-115-01-1-B. Lachat Instruments, Milwaukee, Wis.

Sah, R.N. and R.O. Miller. 1992. Spontaneous reaction for acid dissolution of biological tissues in closed vessels. Anal. Chem. 64:230-233.

Stamps, R.H. and M.R. Evans. 1997. Growth of Dieffenbachia maculata 'Camille' in growing media containing sphagnum peat or coconut coir dust. HortScience 32:844-847.

Stamps, R.H. and M.R. Evans. 1999. Growth of Dracaena marginata and Spathiphyllum 'Petite' in sphagnum peat- and coconut coir dust-based growing media. J. Environ. Hort. 17:49-52.

Sweeney, R.A. 1989. Generic combustion method for determination of crude protein in feeds: Collaborative study. J. Assn. Offic. Anal. Chem. 72:770-774.

U.S. Department of Agriculture. 2003. Floriculture crops 2003 summary. USDA, Wash., D.C.

Wyland, L.J. and L.E. Jackson. 1993. Evaluating nitrate recovery by ion-exchange resin bags. Soil Sci. Soc. Amer. J. 57:1208-1211. 